\title{
KETERLIBATAN KERJA SEBAGAI PEMEDIASI PENGARUH KEPRIBADIAN PROAKTIF DAN PERSEPSI DUKUNGAN ORGANISASIONAL TERHADAP KEPUASAN KERJA
}

\author{
Aurilia Triani Aryaningtyas \\ Program Studi Bina Wisata, Sekolah Tinggi Ilmu Ekonomi Pariwisata Indonesia (STIEPARI) Semarang \\ Email: aurilia.ta@gmail.com
}

Lieli Suharti

Fakultas Ekonomika dan Bisnis, Universitas Kristen Satya Wacana

Email: Lieli.suharti@staff.uksw.edu

\begin{abstract}
Abstrak
Penelitian ini menguji pengaruh kepribadian proaktif dan persepsi dukungan organisasional terhadap kepuasan kerja dengan keterlibatan kerja sebagai variabel mediator, menggunakan data 200 karyawan. Hasil menunjukkan kepribadian proaktif dan persepsi dukungan organisasional secara positif dan signifikan berpengaruh terhadap kepuasan kerja melalui keterlibatan kerja. Implikasi teoritis mendukung teori maupun penelitian yang sudah ada, sedangkan implikasi manajerial menyarankan pada organisasi untuk mempertimbangkan kepribadian proaktif dan persepsi dukungan organisasional sebagai faktor yang cukup penting mendorong karyawan makin terlibat dalam pekerjaannya sehingga dapat meningkatkan kepuasan kerjanya.
\end{abstract}

Kata kunci: Kepribadian proaktif, persepsi dukungan organisasional, keterlibatan kerja dan kepuasan kerja.

\begin{abstract}
This study examined proactive personality effect and perceived organizational support on job satisfaction with job involvement as a mediator variable, using data 200 employees. The results showed proactive personality and perceived organizational support in a positive and significant effect on job satisfaction through job involvement. Theoretical implications supported the theory and existing researches. Manajerial implications suggested the organization to consider proactive personality and perceptions of organizational support as a important factor to encourage more employees involved in work that can improve job satisfaction.
\end{abstract}

Keywords: Proactive personality, perceived of organizational support, job involvement, job satisfaction.

\section{PENDAHULUAN}

Keterlibatan kerja didefinisikan sebagai sejauh mana seseorang mengidentifikasi secara psikologis dengan pekerjaannya atau pentingnya pekerjaan dalam citra diri individu (Lodahl \& Kejner, 1965) Keterlibatan kerja telah muncul sebagai sebuah variabel penting dalam penelitian organisasi dan telah menarik perhatian ilmuwan manajemen maupun psikologi organisasi. Variabel ini memiliki arti penting dalam pengembangan organisasi terlihat dari sejumlah penelitian yang telah dilakukan untuk melihat keterlibatan kerja karyawan pada organisasi (Khan \& Nemati, 2011; Khan et al., 2011; Mudrack, 2004).
Meskipun berbagai penelitian mengenai keterlibatan kerja dengan sejumlah variabel telah diuji, namun beberapa konsep perilaku organisasional fundamental di antaranya seperti konsep kepuasan kerja telah banyak mendapat perhatian (Khan \& Nemati, 2011; Li et al., 2007; Bhargava \& Kelkar, 2001). Kepuasan kerja didefinisikan sebagai suatu keadaan emosional yang menyenangkan atau positif yang dihasilkan dari penilaian pekerjaan atau pengalaman pekerjaan (Locke, 1976). Orang dengan keterlibatan kerja tinggi memfokuskan sebagian besar perhatian pada pekerjaan mereka sehingga menjadi benar-benar tenggelam dan menikmati pekerjaan tersebut. Hal ini merupakan kepercayaan seseorang terhadap pekerjaannya dan merupakan fungsi dari 
seberapa banyak pekerjaan tersebut dapat memuaskan keinginan seseorang (Diefendorff et al., 2006).

Karyawan diharapkan dapat terlibat secara penuh dengan pekerjaan mereka sehingga karyawan dapat menciptakan kinerja yang baik dan akan berpartisipasi aktif dalam menyelesaikan pekerjaan atau tugasnya. Hasil penelitian Khan \& Nemati (2011) serta Putri (2010) menemukan bahwa keterlibatan kerja berpengaruh positif terhadap kepuasan kerja. Hal ini disebabkan karyawan akan lebih merasa puas dan senang jika bisa menghabiskan sebagian besar waktu, tenaga, dan pikiran untuk pekerjaannya.

Membahas keterlibatan kerja juga tidak akan terlepas dari adanya faktor-faktor yang dapat mempengaruhinya. Dalam pendekatan disposisional, keterlibatan dalam pekerjaan dipandang tergantung pada kepribadian individu. Pengaruh yang diberikan oleh beberapa karakteristik pribadi yang stabil akan memastikan individu memiliki sikap kerja yang berbeda. Dua sikap kerja tersebut adalah keterlibatan pekerjaan dan kepuasan kerja. Individu dianggap memiliki sejumlah keinginan atau nilai yang akan mendorong mereka untuk bekerja lebih keras atau menghalangi mereka dari keterlibatan kerja (Akhtar \& Singh, 2010).

Kepribadian proaktif didefinisikan sebagai sebuah disposisi dalam mengambil inisiatif pribadi untuk mempengaruhi lingkungan seseorang (Crant, 2000). Variabel kepribadian proaktif dapat dipertimbangkan sebagai variabel yang berpengaruh terhadap keterlibatan kerja berdasarkan asumsi bahwa kepribadian proaktif menyiratkan kesediaan untuk terlibat dan mengambil inisiatif untuk mengidentifikasi dan memberikan kontribusi pada berbagai kegiatan dan situasi. Oleh karena itu kepribadian proaktif sebagai salah satu karakteristik positif dari individu dianggap dapat berpengaruh terhadap keterlibatan kerja karyawan.

Selain kepribadian proaktif, persepsi dukungan organisasional (Perceived Organisational Supportl POS) juga dapat dipertimbangkan sebagai faktor yang turut mempengaruhi keterlibatan kerja. Eisenberger $e t$ al. (1997), menjabarkan persepsi dukungan organisasional sebagai pemahaman masyarakat secara global mengenai tingkat yang mana organisasi peduli dengan keberadaan dan kontribusi karyawan serta peduli terhadap kesejahteraan mereka.

Adapun alasan mempertimbangkan variabel ini adalah bahwa keterlibatan kerja itu timbul sebagai respon terhadap suatu pekerjaan atau situasi tertentu dalam lingkungan kerja (Rabinowitz \& Hall, 1977). Berdasarkan Teori Pertukaran Sosial (Social Exchange Theory), karyawan cenderung melihat apakah ada sikap atau perilaku menguntungkan dari organisasi yang muncul dari hubungan pertukaran yang terjadi antara karyawan dan pimpinan organisasi (Eisenberger et al., 1997). Informasi di atas dapat menunjukkan pentingnya peran dukungan organisasional untuk para karyawan. Apabila karyawan percaya bahwa organisasi menyediakan dukungan yang mereka perlukan, menilai kontribusi mereka, dan peduli tentang kesejahteraan mereka, maka hal ini dapat meningkatkan keterlibatan kerja karyawan dan selanjutnya meningkatkan kepuasan kerja (Rhoades \& Eisenberger, 2002).

Meskipun sejumlah penelitian mengenai keterlibatan kerja telah dilakukan, namun penelitian yang menguji keterlibatan kerja sebagai mediator yang menghubungkan antara faktor pribadi dan faktor situasional dengan kepuasan kerja masih relatif terbatas. Oleh karena itu penelitian ini bertujuan untuk menjawab beberapa pertanyaan sebagai berikut:

1. Apakah kepribadian proaktif berpengaruh signifikan terhadap keterlibatan kerja karyawan?

2. Apakah persepsi dukungan organisasional berpengaruh signifikan terhadap keterlibatan kerja karyawan?

3. Apakah keterlibatan kerja karyawan berpengaruh signifikan terhadap kepuasan kerja karyawan?

4. Apakah keterlibatan kerja karyawan memediasi hubungan antara kepribadian proaktif dan persepsi dukungan organisasional terhadap kepuasan kerja karyawan?

\section{LANDASAN TEORI DAN HIPOTESIS}

Konsep keterlibatan kerja pertama kali diperkenalkan oleh Lodahl \& Kejner (1965). Mereka menghubungkan keterlibatan kerja pada identifikasi psikologis individu dengan pekerjaan atau pentingnya pekerjaan dalam citra diri individu (Kanungo, 1982). Brown (1996), mengemukakan bahwa seorang karyawan dikatakan terlibat dalam pekerjaannya apabila karyawan tersebut dapat mengidentifikasikan diri secara psikologis dengan pekerjaannya, dan menganggap kinerjanya penting untuk dirinya, selain untuk organisasi.

\section{Kepribadian Proaktif dan Keterlibatan Kerja}

Dalam pendekatan disposisional, keterlibatan dalam pekerjaan dipandang tergantung pada kepribadian individu. Pengaruh yang diberikan oleh beberapa karakteristik pribadi yang stabil akan memastikan individu memiliki sikap kerja yang berbeda. Dua sikap kerja tersebut adalah keterlibatan pekerjaan dan kepuasan kerja. Individu dianggap memiliki sejumlah keinginan atau nilai yang akan 
mendorong mereka untuk bekerja lebih keras atau menghalangi mereka dari keterlibatan kerja (Akhtar \& Singh, 2010). Kepribadian proaktif didefinisikan sebagai sebuah disposisi dalam mengambil inisiatif pribadi untuk mempengaruhi lingkungan seseorang (Crant, 2000). Parker et al. (2006), menyebut individu proaktif sebagai orang-orang yang biasanya melibatkan diri dalam tindakan yang berdampak terhadap diri mereka sendiri dan juga terhadap lingkungan mereka. Oleh karena itu, karyawan dengan kepribadian proaktif selalu berfokus pada masa depan, sadar serta berorientasi pada perubahan.

Berdasarkan pemaparan di atas dapat ditarik suatu kesimpulan bahwa kepribadian proaktif menyiratkan kesediaan untuk terlibat dan mengambil inisiatif untuk mengidentifikasi dan memberikan kontribusi pada berbagai kegiatan dan situasi (Crant, 2000). Apabila tingkat kepribadian proaktif semakin tinggi, maka kesediaan untuk terlibat di dalam pekerjaan akan semakin tinggi pula, maka disusun hipotesis berikut ini.

H1: Kepribadian proaktif berpengaruh signifikan terhadap keterlibatan kerja karyawan.

\section{Persepsi Dukungan Organisasional dan Keter- libatan Kerja}

Peran dukungan organisasional atau POS menjelaskan bahwa organisasi akan menyediakan bantuan sesuai yang dibutuhkan oleh karyawan untuk bekerja secara efektif dan dalam menghadapi situasi yang sulit. Eisenberger et al. (1997) menjabarkan persepsi dukungan organisasi sebagai pemahaman karyawan secara global mengenai tingkat yang mana organisasi peduli dengan keberadaan dan kontribusi karyawan serta peduli terhadap kesejahteraan mereka. Selanjutnya menurut Akhtar \& Singh (2010) Keterlibatan kerja timbul sebagai respon terhadap suatu pekerjaan atau situasi tertentu dalam lingkungan kerja.

Berdasarkan Teori Pertukaran Sosial (Social Exchange Theory), karyawan cenderung melihat apakah ada sikap atau perilaku menguntungkan dari organisasi yang muncul dari hubungan pertukaran yang terjadi antara karyawan dan pimpinan organisasi (Dharmasri \& Vathsala, 2010). Informasi di atas dapat menunjukkan pentingnya peran dukungan organisasional untuk para karyawan. Apabila karyawan percaya bahwa organisasi menyediakan dukungan yang mereka perlukan, menilai kontribusi mereka, dan peduli tentang kesejahteraan mereka, maka hal ini dapat meningkatkan keterlibatan kerja karyawan dan selanjutnya meningkatkan kepuasan kerja (Rhoades \& Eisenberger, 2002). Hal ini juga sejalan dengan hasil penelitian Dharmasri \& Vathsala
(2010) yang menemukan bahwa POS berpengaruh signifikan positif terhadap keterlibatan kerja.

H2: Persepsi dukungan organisasional berpengaruh signifikan terhadap keterlibatan kerja karyawan.

\section{Keterlibatan Kerja dan Kepuasan Kerja}

Kepuasan kerja didefinisikan sebagai suatu keadaan emosional yang menyenangkan atau positif yang dihasilkan dari penilaian pekerjaan atau pengalaman pekerjaan (Locke, 1976). Kepuasan kerja mengacu pada reaksi emosional positif individu untuk pekerjaan tertentu. Kepuasan kerja juga mengenai sejauh mana orang-orang suka (puas) atau tidak suka (tidak puas) pada pekerjaan mereka (Spector, 1997).

Keterlibatan kerja merupakan faktor penting dalam sikap kerja lain yang terkait seperti kepuasan kerja. Orang dengan keterlibatan kerja tinggi memfokuskan sebagian besar perhatian pada pekerjaan mereka sehingga menjadi benar-benar tenggelam dan menikmati pekerjaan tersebut. Hal ini merupakan kepercayaan seseorang terhadap pekerjaannya dan merupakan fungsi dari seberapa banyak pekerjaan tersebut dapat memuaskan keinginan seseorang (Diefendorff et al., 2006).

Dengan adanya keterlibatan secara penuh terhadap pekerjaan, maka karyawan akan menciptakan kinerja yang baik dalam menyelesaikan pekerjaan atau tugasnya dan karyawan akan lebih merasa puas dan senang jika bisa menghabiskan sebagian besar waktu, tenaga, dan pikiran untuk pekerjaannya. Hal ini senada dengan hasil penelitian Khan \& Nemati (2011) serta Putri (2010) yang menemukan bahwa keterlibatan kerja berpengaruh positif terhadap kepuasan kerja.

H3: Keterlibatan kerja karyawan berpengaruh signifikan terhadap kepuasan kerja karyawan.

\section{Peranan Keterlibatan Kerja sebagai variabel Mediator}

Penelitian ini berusaha mengungkapkan adanya pengaruh antara kepribadian proaktif dan persepsi dukungan organisasi terhadap kepuasan kerja akan dimediasi oleh keterlibatan kerja. Secara teoritis, orang yang proaktif akan menampilkan inisiatif untuk mengubah prosedur dalam melakukan pekerjaan dan lingkungan organisasi, dengan demikian cenderung menjadi kreatif (Seibert, Kraimer, \& Crant, 2001). Hal tersebut dapat mendorong individu untuk lebih terlibat dalam pekerjaannya. Orang dengan keterlibatan kerja tinggi memfokuskan sebagian besar perhatian pada pekerjaan mereka sehingga menjadi benar-benar tenggelam dan menikmati pekerjaan 
tersebut. Hal ini merupakan kepercayaan seseorang terhadap pekerjaannya dan merupakan fungsi dari seberapa banyak pekerjaan tersebut dapat memuaskan keinginan seseorang (Diefendorff et al., 2006).

Menurut Brown (1996), karyawan dikatakan terlibat dalam pekerjaannya apabila karyawan tersebut dapat mengidentifikasikan diri secara psikologis dengan pekerjaannya, dan menganggap kinerjanya penting untuk dirinya. Keterlibatan kerja akan terbentuk karena keinginan dari pekerja akan kebutuhan tertentu, nilai atau karakteristik tertentu yang diperoleh dari pekerjaannya sehingga akan membuat pekerja tersebut lebih terlibat atau tidak terlibat pada pekerjaannya. Selain itu apabila karyawan percaya bahwa organisasi menyediakan dukungan yang mereka perlukan, menilai kontribusi mereka, dan peduli tentang kesejahteraan mereka, maka hal ini dapat meningkatkan keterlibatan kerja karyawan dan selanjutnya meningkatkan kepuasan kerja (Eisenberger et al., 1997).

H4: Keterlibatan kerja karyawan memediasi pengaruh kepribadian proaktif terhadap kepuasan kerja karyawan.

H5: Keterlibatan kerja karyawan memediasi pengaruh persepsi dukungan organisasional terhadap kepuasan kerja karyawan.

Model penelitian ini dapat dilihat dalam Gambar 1.

\section{METODE PENELITIAN}

\section{Pemilihan Sampel dan Pengumpulan Data}

Penelitian ini merupakan jenis penelitian eksplanatori (explanatory research). Populasi dalam penelitian ini adalah seluruh mahasiswa Program Pasca Sarjana STIEPARI Semarang yang masih aktif kuliah pada semester genap tahun 2011/2012 dan berstatus sebagai karyawan pada suatu instansi/ perusahaan dan secara total mereka berjumlah 216 orang. Teknik sampling yang digunakan adalah saturation sampling, dimana seluruh anggota populasi dijadikan responden penelitian ini. Pengumpulan data dalam penelitian ini dilakukan dengan penyebaran kuesioner terstruktur. Kuesioner yang kembali sebanyak 211 set, namun hanya 200 yang terisi lengkap dan layak digunakan dalam analisis data. Profil responden secara umum didominasi oleh mereka yang berjenis kelamin laki-laki $(57,5 \%)$, berumur antara 35-45 tahun (57\%), memiliki pekerjaan sebagai pegawai negeri sipil $(88 \%)$ dengan masa kerja 11 - 20 tahun (52\%).

\section{Definisi Operasional dan Pengukuran Variabel}

Penelitian ini menggunakan empat variabel yaitu Kepribadian Proaktif (Proactive Personality),

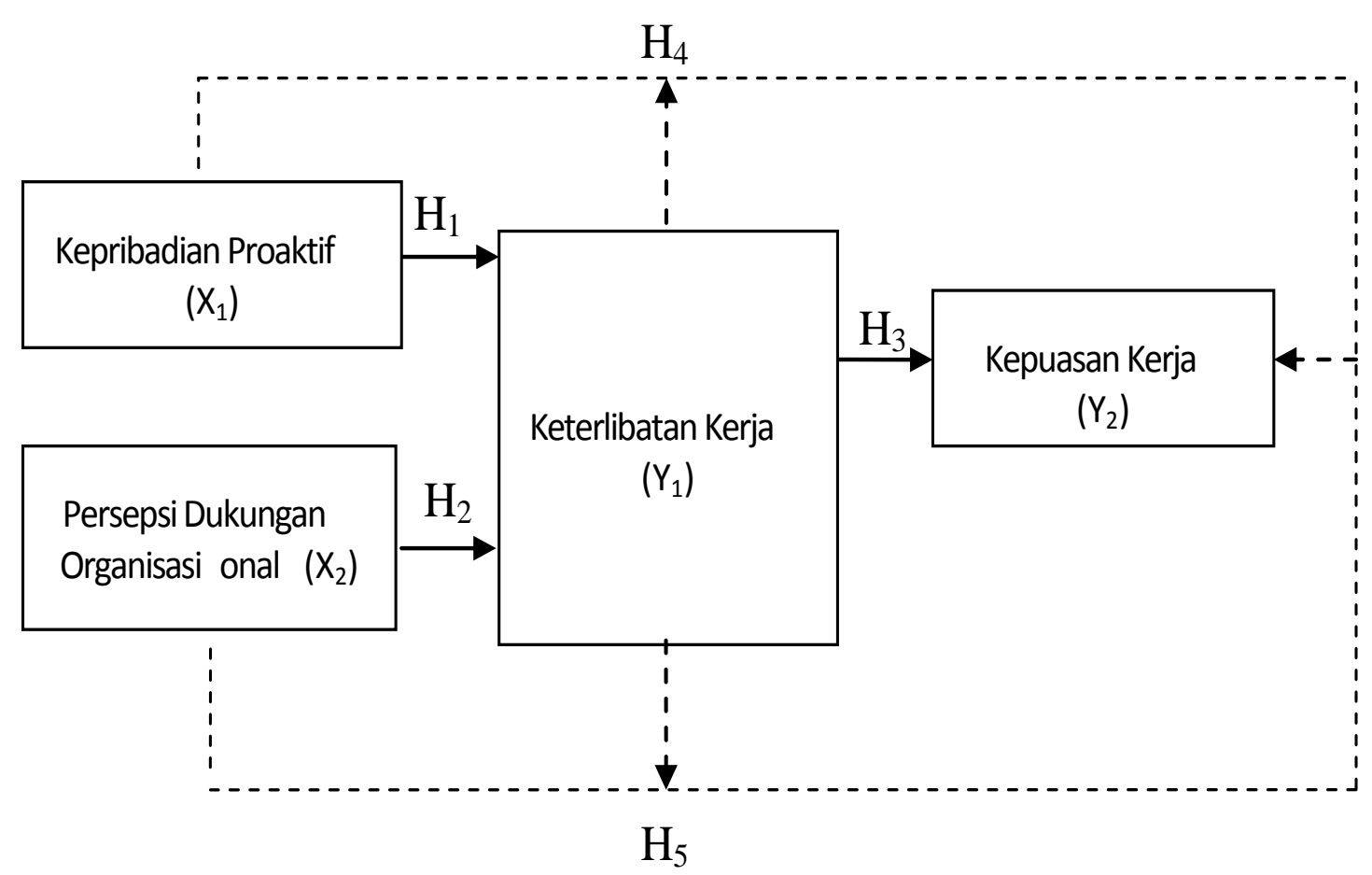

Gambar 1. Model Penelitian 
Persepsi Dukungan Organisasional (Perceived Organisational Support), Keterlibatan Kerja (Job Involvement) dan Kepuasan Kerja (Job Satisfaction). Pengukuran menggunakan skala Likert tujuh point (1 $=$ sangat tidak setuju sampai 7 = sangat setuju).

\section{Kepribadian Proaktif (Proactive Personality)}

Kepribadian proaktif diukur dengan 10 item pertanyaan yang merupakan modifikasi dari item pertanyaan dalam penelitian sebelumnya (Seibert, Crant, \& Kraimer, 1999; Crant, 2000; Fuller, Hester \& Cox, 2010). Pertanyaan yang diajukan antara lain mengenai perilaku karyawan dalam mencari cara baru untuk meningkatkan hidup, membuat perubahan yang konstruktif, merubah ide menjadi kenyataan, memperbaiki sesuatu, membuat segala kemungkinan menjadi kenyataan, memperjuangkan ide-ide, keunggulan dalam mengidentifikasi peluang, mencari cara yang lebih baik dalam melakukan sesuatu, kemampuan mewujudkan ide menjadi suatu kenyataan, dan kemampuan melihat kesempatan. Uji reliabilitas menunjukkan semua item dari pengukuran ini reliabel dengan Cronbach alpha sebesar 0,92.

\section{Persepsi Dukungan Organisasional (Perceived Organisational Support)}

Persepsi dukungan organisasional diukur dengan 8 item pertanyaan dari 36 item original yang dikembangkan dalam Survei Persepsi Dukungan Organisasional oleh Eisenberger et al. (1997) dan Dharmasri \& Vathsala (2010). Pertanyaannya antara lain mengenai persepsi terhadap kepedulian organisasi terhadap pendapat karyawan, kepedulian organisasi terhadap kesejahteraan karyawan, kepedulian organisasi terhadap tujuan dan nilai-nilai karyawan, kepedulian organisasi dalam memberikan bantuan terhadap masalah karyawan, kepedulian organisasi dalam memberikan maaf atas kesalahan karyawan, keinginan organisasi untuk mengambil keuntungan dari karyawan, perhatian dari organisasi terhadap karyawan, kepedulian organisasi dalam memberikan bantuan khusus bagi karyawan. Uji reabilitas menunjukkan semua item reliabel dengan Cronbach alpha sebesar 0,87.

\section{Keterlibatan kerja (job involvement)}

Keterlibatan kerja diukur dengan skala 10 item keterlibatan kerja yang dibuat oleh Kanungo (1982) dan telah dikembangkan dalam penelitian Khan et al. (2011). Pertanyaannya antara lain mengenai pentingnya terlibat dalam pekerjaan, porsi pekerjaan dalam diri karyawan, keterlibatan secara pribadi dalam pekerjaan, pentingnya pekerjaan bagi kehidupan, ketertarikan untuk terpusat dalam pekerjaan, keterikatan dengan pekerjaan, perasaan terlepas dari pekerjaan, kaitan antara pekerjaan dengan tujuan hidup, pekerjaan merupakan pusat keberadaan karyawan, kesenangan terlibat dalam pekerjaan. Uji validitas menunjukkan ada dua item yang tidak valid sehingga tidak dipergunakan dalam pengukuran. Cronbach's alpha untuk skala ini adalah 0,92.

\section{Kepuasan Kerja (Job Satisfaction)}

Kepuasan kerja diukur dengan 8 item dari 16 item original menggunakan empat sub-skala dari Survei Kepuasan Kerja (Job Satisfaction Survey/ JSS) yang dikembangkan oleh Spector (1997) yang juga digunakan dalam penelitian Prabhu (2007). Pertanyaan-pertanyaan yang diajukan antara lain mengenai kepuasan terhadap kompensasi disamping pembayaran/gaji pokok yang diterima, manfaat yang diterima dibanding dengan yang ditawarkan organisasi lain, penghargaan yang sesuai untuk pekerjaan yang dilakukan, perasaan dihargai karena pekerjaannya, rasa bangga dalam melakukan pekerjaan, rasa senang terhadap pekerjaan, komunikasi dalam organisasi, kejelasan tujuan organisasi. Uji reliabilitas menunjukkan semua item reliabel dengan Cronbach alpha 0,84 .

\section{Teknik Analisis}

Sebelum dilakukan pengujian hipetesis, dilakukan dulu uji asumsi klasik yang meliputi uji normalitas, uji multikolinearitas, heteroskedastisitas. Hasil uji asumsi klasik menunjukkan data terdistribusi dengan normal, tidak terjadi multikolinearitas dan heteroskedastisitas. Setelah itu dilanjutkan dengan pengujian hipotesis dengan menggunakan analisis regresi berganda dan regresi sederhana. Regresi berganda digunakan untuk menguji variabel Kepribadian Proaktif $\left(\mathrm{X}_{1}\right)$ dan Persepsi Dukungan Organisasional $\left(\mathrm{X}_{2}\right)$ sebagai variabel independen terhadap Keterlibatan Kerja $\left(Y_{1}\right)$ sebagai variabel dependen. Pengujian hipotesis dengan regresi sederhana untuk menguji pengaruh Keterlibatan Kerja $\left(\mathrm{Y}_{1}\right)$ terhadap Kepuasan $\operatorname{Kerja}\left(\mathrm{Y}_{2)}\right.$.

Uji mediasi menggunakan uji statistik product of coefficient yang didasarkan pada pengujian signifikansi pengaruh tak langsung atau indirect effects dengan menggunakan dua teknik yaitu Sobel test versi Aroian yang dipopulerkan dan direkomendasikan oleh Baron \& Kenny (1986) dan teknik resampling yaitu bootstrapping menggunakan macro yang dibuat oleh Preacher \& Hayes (2008). 


\section{HASIL PENELITIAN DAN PEMBAHASAN}

Ringkasan statistik deskriptif dari masingmasing variabel terlihat dalam Tabel 1.

Tabel 1. Descriptive Statistics

\begin{tabular}{|c|c|c|c|c|c|}
\hline & $\mathrm{N}$ & $\begin{array}{l}\text { Mini- } \\
\text { mum }\end{array}$ & $\begin{array}{l}\text { Maxi- } \\
\text { mum }\end{array}$ & Mean & $\begin{array}{c}\text { Std. } \\
\text { Deviation }\end{array}$ \\
\hline $\begin{array}{l}\text { Kepribadian } \\
\text { Proaktif }\end{array}$ & 200 & 1.00 & 7.00 & 5.1295 & 1.27377 \\
\hline $\begin{array}{l}\text { Persepsi Dukung- } \\
\text { an Organisasional }\end{array}$ & 200 & 1.00 & 7.00 & 5.1179 & 1.08962 \\
\hline Keterlibatan Kerja & 200 & 1.00 & 7.00 & 5.3452 & 1.19044 \\
\hline Kepuasan Kerja & 200 & 1.00 & 7.00 & 5.4118 & .99307 \\
\hline Valid N (listwise) & 200 & & & & \\
\hline
\end{tabular}

Sumber: Data primer, diolah. 2012

Dari Tabel 1 dapat dilihat bahwa total rata-rata skor tiap variabel di atas 5,00. Hal ini menunjukkan bahwa tingkat kepribadian proaktif, persepsi dukungan organisasional, keterlibatan kerja maupun kepuasan kerja karyawan yang sedang menempuh studi lanjut di Program Pascasarjana STIEPARI Semarang termasuk dalam kategori tinggi.

\section{Pengaruh Kepribadian Proaktif dan Persepsi Dukungan Organisasional terhadap Keterlibatan Kerja}

Dari Tabel 2 terlihat besarnya koefisien determinasi $\mathrm{R}^{2}=0,416$ menunjukkan bahwa $41,6 \%$ keterlibatan kerja dipengaruhi oleh kepribadian proaktif dan persepsi dukungan organisasional, sisanya $58,4 \%$ dipengaruhi oleh variabel lain. Uji Anova menunjukkan $\mathrm{F}$ hitung sebesar 70,026 > F tabel sebesar 3,04 dengan tingkat signifikansi $0,000<$ 0,050 yang berarti kontribusi variabel kepribadian proaktif dan persepsi dukungan organisasional signifikan dalam memprediksi nilai variabel keterlibatan kerja.

Koefisien regresi sebesar 0,313 kepribadian proaktif terhadap keterlibatan kerja adalah positif. Adapun nilai $\mathrm{t}$ hitung sebesar 5,776 $>\mathrm{t}$ tabel $(\mathrm{df}=$ 200) sebesar 1,960 dan signifikansi $0,000<0,050$ menunjukkan bahwa kepribadian proaktif berpenga- ruh secara signifikan terhadap keterlibatan kerja, dengan demikian hipotesis 1 dapat diterima.

Koefisien regresi sebesar 0,488 menunjukkan persepsi dukungan organisasional berpengaruh positif terhadap keterlibatan kerja. Adapun nilai t hitung sebesar 7,697 > t tabel $(\mathrm{df}=200)$ sebesar 1,960 dan signifikansi $0,000<0,050$ menunjukkan bahwa persepsi dukungan organisasional berpengaruh secara signifikan terhadap keterlibatan kerja, dengan demikian hipotesis 2 dapat diterima.

\section{Pengaruh Keterlibatan Kerja terhadap Kepuasan Kerja}

Dari Tabel 2 terlihat besarnya koefisien determinasi $\mathrm{R}^{2}=0,444$, hal ini menunjukkan bahwa $44,4 \%$ kepuasan kerja dipengaruhi oleh keterlibatan kerja, sisanya 55,6\% dipengaruhi oleh variabel lain. Uji Anova mendapatkan F hitung sebesar 158,113 > F tabel sebesar 3,89 dengan tingkat signifikansi 0,000 < 0,050 yang berarti kontribusi variabel keterlibatan kerja signifikan dalam memprediksi nilai variabel kepuasan kerja.

Koefisien regresi sebesar 0,556 menyatakan keterlibatan kerja berpengaruh positif terhadap kepuasan kerja. Adapun nilai t hitung sebesar 12,574 $>\mathrm{t}$ tabel $(\mathrm{df}=200)$ sebesar 1,960 dan signifikansi $0,000<0,050$ menunjukkan bahwa kepribadian proaktif berpengaruh secara signifikan terhadap keterlibatan kerja, dengan demikian hipotesis 3 dapat diterima.

\section{Pengaruh Kepribadian Proaktif terhadap Kepuasan Kerja dengan Keterlibatan Kerja sebagai Variabel Mediator}

Pengaruh Kepribadian Proaktif terhadap Kepuasan Kerja dengan Keterlibatan Kerja sebagai Variabel Mediator dapat dilihat dalam Tabel 3.

Berdasarkan hasil uji mediasi, dapat dilihat bahwa variabel independen tidak lagi mempunyai pengaruh terhadap variabel dependen setelah mengontrol variabel mediator, yaitu dengan koefisien sebesar 0,0734 dan signifikansi 0,1219, maka dinyatakan terjadi perfect atau complete mediation antara kepribadian proaktif $\left(\mathrm{X}_{1}\right)$ dan kepuasan kerja

Tabel 2. Hasil Analisis Regresi

\begin{tabular}{lcccccc}
\hline \multicolumn{1}{c}{ Model } & Koefisien regresi & Nilai Uji t & Sig. & Nilai Uji F & Sig. & R $^{2}$ \\
\hline Kep_Proaktif $\left(\mathrm{X}_{1}\right) \rightarrow$ Ket_Kerja $\left(\mathrm{Y}_{1}\right)$ & 0.313 & 5.776 & 0.000 & \multirow{2}{*}{70.026} & 0.000 & 0.416 \\
Persepsi_DO $\left(\mathrm{X}_{2}\right) \rightarrow$ Ket_Kerja $\left(\mathrm{Y}_{1}\right)$ & 0.488 & 7.697 & 0.000 & & & \\
Ket_Kerja $\left(\mathrm{Y}_{1}\right) \rightarrow$ Kep_Kerja $\left(\mathrm{Y}_{2}\right)$ & 0.556 & 12.574 & 0.000 & 158.113 & 0,000 & 0,444 \\
\hline S
\end{tabular}

Sumber: Data primer, diolah. 
Tabel 3. Hasil Uji Mediasi dengan Sobel Test

\begin{tabular}{|c|c|c|c|c|}
\hline \multicolumn{5}{|c|}{ DIRECT \& TOTAL EFFECTS } \\
\hline & Coeff & se & $\mathrm{t}$ & Sig (two) \\
\hline $\mathrm{b}(\mathrm{YX})$ & .3101 & .0508 & 6.1009 & .0000 \\
\hline $\mathrm{b}(\mathrm{MX})$ & .4576 & .0579 & 7.9019 & .0000 \\
\hline b(YM.X) & .5174 & .0505 & 10.2422 & .0000 \\
\hline b(YX.M) & .0734 & .0472 & 1.5536 & .1219 \\
\hline \multicolumn{5}{|c|}{ INDIRECT EFFECT \& SIGNIFICANCE USING NORMAL DISTRIBUTION } \\
\hline & Value & se & $\mathrm{Z}$ & Sig (two) \\
\hline Effect & .2368 & .0380 & 6.2377 & .0000 \\
\hline \multicolumn{5}{|c|}{ BOOTSTRAP RESULTS For INDIRECT EFFECT } \\
\hline & Data & se & LL 95 CI & UL 95 CI \\
\hline Effect & .2368 & .0593 & .1328 & .3677 \\
\hline
\end{tabular}

Sumber: Hasil estimasi, diolah.

Tabel 4. Hasil Uji Mediasi dengan Sobel Test

\begin{tabular}{|c|c|c|c|c|}
\hline \multicolumn{5}{|c|}{ DIRECT \& TOTAL EFFECTS } \\
\hline & Coeff & se & $\mathrm{t}$ & Sig (two) \\
\hline $\mathrm{b}(\mathrm{YX})$ & .4419 & .0566 & 7.8019 & .0000 \\
\hline $\mathrm{b}(\mathrm{MX})$ & .6147 & .0642 & 9.5763 & .0000 \\
\hline b(YM.X) & .4803 & .0527 & 9.1059 & .0000 \\
\hline $\mathrm{b}(\mathrm{YX} . \mathrm{M}) \quad \mathrm{c}$ & .1467 & .0576 & 2.5458 & .0117 \\
\hline \multicolumn{5}{|c|}{ INDIRECT EFFECT \& SIGNIFICANCE USING NORMAL DISTRIBUTION } \\
\hline & Value & se & $\mathrm{Z}$ & Sig (two) \\
\hline Effect & 2952 & .0449 & 6.5801 & .0000 \\
\hline \multicolumn{5}{|c|}{ BOOTSTRAP RESULTS For INDIRECT EFFECT } \\
\hline & Data & se & LL 95 CI & UL 95 CI \\
\hline Effect & .2952 & .0751 & .1610 & .4506 \\
\hline
\end{tabular}

Sumber: Hasil estimasi, diolah.

$\left(\mathrm{Y}_{2}\right)$ melalui mediator keterlibatan kerja $\left(\mathrm{Y}_{1}\right)$ (Kenny, 2008; Preacher dan Hayes, 2004).

Pengujian signifikansi indirect effect dengan Sobel test diperoleh nilai $\mathrm{z}=6,2377$ dan $\mathrm{p}=0,0000$. Karena $z$-value dalam harga mutlak $>1,96$ dan tingkat signifikansi statistik z $(p$-value $)<0,05$, berarti indirect effect atau pengaruh tak langsung variabel independen terhadap variabel dependen melalui mediator, signifikan pada taraf signifikansi 0,05. Hasil ini menunjukkan signifikansi indirect effect kepribadian proaktif $\left(\mathrm{X}_{1}\right)$ dan kepuasan kerja $\left(\mathrm{Y}_{2}\right)$ melalui mediator keterlibatan kerja $\left(\mathrm{Y}_{1}\right)$.

Adapun pengujian signifikansi indirect effect dengan bootstrapping diperoleh estimasi true indirect effect yang berkisar antara 0,1328 - 0,3677 pada 95\% confidence interval. Karena nol tidak terkandung dalam confidence interval tersebut, maka dapat disimpulkan bahwa indirect effect signifikan pada taraf signifikansi 5\%. Jadi sejalan dengan hasil Sobel test, indirect effect kepribadian proaktif $\left(\mathrm{X}_{1}\right)$ dan kepuasan kerja $\left(\mathrm{Y}_{2}\right)$ melalui mediator keterlibatan kerja $\left(\mathrm{Y}_{1}\right)$ signifikan pada taraf signifikansi 0.05 . Dengan demikian hipotesis 4 dapat diterima.

\section{Pengaruh Persepsi Dukungan Organisasional terhadap Kepuasan Kerja dengan Keterlibatan Kerja sebagai Variabel Mediator}

Pengaruh Persepsi Dukungan Organisasional terhadap Kepuasan Kerja dengan Keterlibatan Kerja sebagai Variabel Mediator dapat dilihat dalam Tabel 4.

Berdasarkan hasil uji mediasi, pengaruh variabel independen terhadap variabel dependen berkurang tetapi masih signifikan, setelah mengontrol variabel mediator, yaitu dengan koefisien sebesar 0,1467 dan signifikansi 0,0117, maka dinyatakan terjadi partial mediation antara persepsi dukungan organisasional $\left(\mathrm{X}_{2}\right)$ dan kepuasan kerja $\left(\mathrm{Y}_{2}\right)$ melalui mediator keterlibatan kerja $\left(\mathrm{Y}_{1}\right)$. Pengujian signifikansi indirect effect dengan Sobel test diperoleh nilai $\mathrm{z}=6,5801$ dan $\mathrm{p}=0,0000$. Karena $z$-value dalam harga mutlak > 1,96 dan tingkat signifikansi statistik z ( $p$-value) < 0,05 , berarti indirect effect atau pengaruh tak langsung variabel independen terhadap variabel dependen melalui mediator, signifikan pada taraf signifikansi 0,05 . Hasil ini menunjukkan signifikansi indirect 
effect persepsi dukungan organisasional $\left(\mathrm{X}_{2}\right)$ dan kepuasan kerja $\left(\mathrm{Y}_{2}\right)$ melalui mediator keterlibatan $\operatorname{kerja}\left(\mathrm{Y}_{1}\right)$.

Adapun pengujian signifikansi indirect effect dengan bootstrapping diperoleh estimasi true indirect effect yang berkisar antara 0,1610 - 0,4506 pada 95\% confidence interval. Karena nol tidak terkandung dalam confidence interval tersebut, maka dapat disimpulkan bahwa indirect effect signifikan pada taraf signifikansi 5\%. Jadi sejalan dengan hasil Sobel test, indirect effect persepsi dukungan organisasional $\left(\mathrm{X}_{2}\right)$ dan kepuasan kerja $\left(\mathrm{Y}_{2}\right)$ melalui mediator keterlibatan kerja $\left(\mathrm{Y}_{1}\right)$ signifikan pada taraf signifikansi 0.05 . Dengan demikian hipotesis 5 dapat diterima.

\section{Pembahasan}

Hasil penelitian ini menunjukkan kepribadian proaktif berpengaruh positif dan signifikan terhadap keterlibatan kerja. Penelitian ini mendukung pendapat Crant (2000), yang menyatakan bahwa kepribadian proaktif menyiratkan kesediaan untuk terlibat dan mengambil inisiatif untuk mengidentifikasi dan memberikan kontribusi pada berbagai kegiatan dan situasi. Selain itu juga sesuai dengan pendapat Parker et al. (2006) yang menyebut individu proaktif sebagai orang-orang yang biasanya melibatkan diri dalam tindakan yang berdampak pada diri mereka sendiri dan lingkungan mereka. Hal ini menunjukkan bahwa kepribadian proaktif merupakan variabel yang penting dan perlu mendapat perhatian bagi organisasi di Indonesia. Organisasi di Indonesia dapat mempertimbangkan kepribadian proaktif sebagai bagian dari satu set kriteria yang lebih luas untuk menyeleksi dan mempromosikan karyawan agar dapat meningkatkan keterlibatan kerja karyawan. Hal penting yang perlu diperhatikan di sini, bahwa karyawan proaktif menyiratkan kesediaan untuk terlibat dan mengambil inisiatif untuk mengidentifikasi dan memberikan kontribusi pada berbagai kegiatan dan situasi. Dengan demikian organisasi perlu memberi kesempatan yang luas bagi karyawan proaktif untuk terlibat dan mengambil inisiatif serta memberikan kontribusi pada berbagai kegiatan dalam organisasi agar dapat meningkatkan kepuasan kerja.

Penelitian ini juga membuktikan persepsi dukungan organisasional berpengaruh positif dan signifikan terhadap keterlibatan kerja, hal ini mendukung pendapat Rabinowitz dan Hall (1977), yang menyatakan bahwa keterlibatan kerja itu timbul sebagai respon terhadap suatu pekerjaan atau situasi tertentu dalam lingkungan kerja. Dengan lain kata, suatu jenis pekerjaan atau situasi dalam lingkungan kerja akan memengaruhi orang tersebut makin terlibat atau tidak dalam pekerjaannya. Hal ini juga memperkuat pentingnya memberi dukungan bagi karyawan di tempat kerja. Kenyataan menunjukkan bahwa dukungan organisasional yang tinggi dapat menyebabkan karyawan makin terlibat dalam pekerjaannya sekaligus memungkinkan organisasi untuk dapat menciptakan kepuasan kerja karyawan. Dengan demikian hasil penelitian ini juga mendukung hasil penelitian Dharmasri \& Vathsala (2010) yang menemukan bahwa POS berpengaruh signifikan positif terhadap keterlibatan kerja.

Keterlibatan kerja merupakan faktor penting dalam sikap kerja lain yang terkait seperti kepuasan kerja. Orang dengan keterlibatan kerja tinggi memfokuskan sebagian besar perhatian pada pekerjaan mereka sehingga menjadi benar-benar tenggelam dan menikmati pekerjaan tersebut. Hal ini merupakan kepercayaan seseorang terhadap pekerjaannya dan merupakan fungsi dari seberapa banyak pekerjaan tersebut dapat memuaskan keinginan seseorang (Diefendorff et al., 2006). Hasil penelitian ini sejalan dengan hal tersebut dan mendukung hasil penelitian Khan \& Nemati (2011) serta Putri (2010) yang menemukan bahwa keterlibatan kerja berpengaruh positif terhadap kepuasan kerja. Selain ketiga hal di atas, sumbangan terpenting dari penelitian ini adalah dipahaminya pentingnya peran keterlibatan kerja sebagai pemediasi dalam pengaruh faktor kepribadian proaktif dan persepsi dukungan organisasi terhadap kepuasan kerja.

Secara keseluruhan temuan dari model penelitian ini mendukung dan memperkuat Teori Pertukaran Sosial (Social Exchange Theory), yaitu karyawan cenderung akan memberikan tindak balas tertentu berdasarkan persepsi mereka terhadap apa yang telah mereka dapatkan dari perusahaan atau organisasi. Penelitian ini menunjukkan pentingnya peran dukungan organisasional untuk para karyawan sebagai salah satu hal yang dapat meningkatkan keterlibatan kerja karyawan dan selanjutnya meningkatkan kepuasan kerja mereka. Penelitian ini pada akhirnya juga menunjukkan bahwa adanya dukungan dari organisasi disertai karyawan yang memiliki kepribadian proaktif di tempat kerja akan mendorong karyawan untuk lebih terlibat dalam pekerjaannya dan pada akhirnya dapat meningkatkan kepuasan karyawan di tempat kerja.

\section{SIMPULAN DAN SARAN}

Berdasarkan hasil penelitian yang diperoleh, maka terdapat beberapa hal yang dapat disimpulkan dalam penelitian ini sesuai dengan tujuan yang telah 
ditetapkan, yaitu terbukti bahwa kepribadian proaktif berpengaruh positif dan signifikan terhadap keterlibatan kerja, persepsi dukungan organisasional berpengaruh positif dan signifikan terhadap keterlibatan kerja, keterlibatan kerja berpengaruh positif dan signifikan terhadap kepuasan kerja. Selain itu terbukti pula bahwa keterlibatan kerja merupakan variabel mediator yang signifikan bagi pengaruh kepribadian proaktif terhadap kepuasan kerja dan juga merupakan variabel mediator yang signifikan bagi pengaruh persepsi dukungan organisasional terhadap kepuasan kerja.

Hasil penelitian ini memiliki implikasi praktis dengan temuan bahwa kepribadian proaktif merupakan variabel yang berpengaruh terhadap keterlibatan kerja karyawan. Organisasi di Indonesia, terutama yang keterlibatan kerja karyawannya rendah dapat mempertimbangkan kepribadian proaktif sebagai bagian dari satu set kriteria yang lebih luas untuk menyeleksi dan mempromosikan karyawan agar dapat meningkatkan keterlibatan kerja dan kepuasan kerja karyawan. Namun hal penting yang perlu diperhatikan di sini, bahwa karyawan proaktif menyiratkan kesediaan untuk terlibat dan mengambil inisiatif untuk mengidentifikasi dan memberikan kontribusi pada berbagai kegiatan dan situasi. Dengan demikian organisasi perlu memberi kesempatan yang luas serta menciptakan atmosfir yang mendukung bagi karyawan proaktif untuk terlibat dan mengambil inisiatif serta memberikan kontribusi pada berbagai kegiatan dalam organisasi agar dapat meningkatkan kepuasan kerja.

Hasil penelitian juga memperkuat pentingnya suatu organisasi memberi dukungan bagi karyawan di tempat kerja. Kenyataan menunjukkan bahwa dukungan organisasional yang tinggi dapat menyebabkan karyawan makin terlibat dalam pekerjaannya sekaligus memungkinkan organisasi untuk dapat menciptakan kepuasan kerja karyawan sehingga kemungkinan organisasi dapat menuai keuntungan dari inisiatif pribadi karyawan semakin besar.

Penelitian yang telah dilakukan ini masih memiliki kelemahan dikarenakan adanya beberapa keterbatasan, antara lain karena penelitian ini hanya dilakukan pada lokasi penelitian yang terbatas, yaitu mahasiswa pascasarjana STIEPARI Semarang. Meskipun responden berasal dari berbagai bidang pekerjaan maupun berbagai daerah, namun kiranya hasil penelitian ini tidak dapat digeneralisasikan dan harus diinterpretasikan secara hati-hati. Adanya perbedaan karakteristik profil responden seperti umur, jenis kelamin, bidang pekerjaan yang belum dielaborasi dan dianalisis lebih jauh merupakan kelemahan tersendiri dari penelitian ini.
Penelitian mendatang dapat melakukan beberapa pengembangan dari penelitian ini, misalnya dapat dilakukan pengujian ualng model yang sama pada sampel yang berbeda untuk mengetahui konsistensi hasil penelitian ini. Selain itu dapat dilakukan penyempurnaan model dengan menambahkan variabel-variabel lain yang dirasa relevan pada kelompok variabel bebas maupun variabel tergantungnya. Dapat juga dicoba menggunakan metode penelitian yang berbeda untuk memperoleh pemahaman yang lebih baik dan hasil yang lebih akurat.

\section{DAFTAR REFERENSI}

Akhtar, Z. \& Singh, U. 2010. Job Involvement: A Theoretical Interpretation in Different Work Settings. Research Report. Dept. of Psychology Karim City College.

Baron, R. M. \& Kenny, D. A. 1986. The ModeratorMediator Variable Distinction in Social Psychological Research: Conceptual, Strategic and Statistical Considerations. Journal of Personality and Social Psychology, 51, 1173-1182.

Bhargava, S. \& Kelkar, A. 2001. Examining the Relationship between Organisational Structure, Job Involvement, Job Satisfaction, and Empowerment: Implications for Human Resource Development. International Journal of Human Resources Development and Management, 1(2/3/4): 150-161.

Brown, S. P. 1996. A Meta-Analysis and Review of Organizational Research on Job Involvement. Psychological Bulletin, 120: 235-255.

Crant, J. M. 2000. Proactive Behavior in Organizations. Journal of Management, 26: 435-462.

Dharmasri W. \& Vathsala W. 2010. Perceived Organisational Support, Job Involvement and Turnover Intention in Lean Production in Sri Lanka. Original Article Int J Adv Manuf Technol. Springer-Verlag London.

Diefendorff, J. M., Richard, E. M. \& Gosserand, R. H. 2006. Examination of Situational and Attitudinal Moderators of the Hesitation and Performance Relation. Personnel Psychology, 59: 365-393.

Eisenberger, R., Cummings, J., Armeli S. \& Lynch P. 1997. Perceived Organizational Support, Discretionary Treatment, and Job Satisfaction. Journal of Applied Psychology, 82(5): 812-820.

Fuller, J. B., Hester, K. \& Cox, S. S. 2010, Proactive Personality and Job Performance: Exploring Job Autonomy as a Moderator. Journal of Managerial Issues, 22(1). 
Kanungo. R. N. 1982. Measurement of Job and Work Involvement. Journal of Applied Psychology, 67(3): 341-349.

Kenny, D. A. 2008. Mediation. (http://davidakenny. net/cm/mediate.htm, diakses 21 Februari 2012).

Khan, K. \& Nemati, A. R. 2011. Impact of Job Involvement on Employee Satisfaction: A Study Based on Medical Doctors Working at Riphah International University Teaching Hospitals in Pakistan. African Journal of Business Managemen, 5(6): 2241-2246.

Khan, T. I. et al. 2011. Job Involvement as Predictor of Employee Commitment: Evidence from Pakistan. International Journal of Business and Management, 6(4): 252-262.

Li, I. C., Lin, M. C. \& Chen, C. M. 2007. Relationship Between Personality Traits, Job Satisfaction, and Job Involvement Among Taiwanese Community Health Volunteers. Public Health Nurse, May-Jun; 24(3): 274-282.

Locke, E. (1976). The Nature and Causes of Job Satisfaction. In M. D. Dunnette (Ed.). Handbook of Industrial and Organizational Psychology (1297-1349). Chicago: Rand McNally.

Lodahl T, \& Kejner M. 1965. The Definition and Measurement of Job Involvement, Journal of Applied Psycholog, 49(1): 24-33.

Mudrack P. E. 2004. Job Involvement, ObsessiveCompulsive Personality Traits, and Workaholic Behavioral Tendencies. Journal of Organization Change Manage, 17 (5): 490-508.

Parker, S. K., Williams, H. M., \& Turner, N. 2006. Modeling The Antecedents of Proactive Behavior at Work. Journal of Applied Psychology, 91: $636-652$.
Prabhu, V. P. 2007. Understanding The Effect of Proactive Personality on Job related Outcomes in an Organizational Change Setting. Dissertation. The Graduate Faculty of Auburn University.

Preacher, K. J. \& Hayes, A. F. 2004. SPSS and SAS Procedures for Estimating Indirect Effects in Simple Mediation Models. Behavior Research Methods, Instruments, and Computers, 36(4): 717-731. Psychonomic Society, Inc.

Preacher, K. J. \& Hayes, A. F. 2008. Asymptotic and Resampling Strategies for Assessing and Comparing Indirect Effects in Multiple Mediator Models. Behavior Research Methods, 40: 879891.

Putri, H. A. 2010. Pengaruh Keterlibatan Kerja Terhadap Kepuasan Kerja Karyawan Pada PT. Garuda Indonesia Airways Medan. Skripsi. Universitas Sumatera Utara Medan.

Rabinowitz, S. \& Hall, D. T. 1977. Organizational Research on Job Involvement. Psychological Bulletin, 84(2): 265-288.

Rhoades \& Eisenberger. 2002. Perceived Organization Support: A Review of The Literatur. Journal of Psychology, 87(4): 698-714.

Seibert, S. E., Crant, J. M. \& Kraimer, M. L. 1999. Proactive Personality and Career Success. Journal of Applied Psychology, 84: 416-427.

Seibert, S. E., Kraimer, M. L. \& Crant, J. M. 2001. What do Proactive People Do? A Longitudinal Model Linking Proactive Personality and Career Success. Personnel Psychology, 54: 845-974.

Spector, P. E. 1997. Job Satisfaction Application, Assessment, Causes, and Consequences. Thousand Oaks, CA: Sage Publication. 